Maurice A. Deane School of Law at Hofstra University Scholarly Commons at Hofstra Law

Hofstra Law Faculty Scholarship

2001

\title{
UN Sanctions on Afghanistan: A Feminist Perspective
}

Barbara J. Stark

Maurice A. Deane School of Law at Hofstra University

Follow this and additional works at: https://scholarlycommons.law.hofstra.edu/faculty_scholarship

\section{Recommended Citation}

Barbara J. Stark, UN Sanctions on Afghanistan: A Feminist Perspective, 9524 (2001)

Available at: https://scholarlycommons.law.hofstra.edu/faculty_scholarship/1179

This Article is brought to you for free and open access by Scholarly Commons at Hofstra Law. It has been accepted for inclusion in Hofstra Law Faculty Scholarship by an authorized administrator of Scholarly Commons at Hofstra Law. For more information, please contact lawcls@hofstra.edu. 
That the Taliban has engaged in massive human rights violation seems obvious. One may even argue that the Taliban does harbor "terrorists," though the label terrorism is invoked selectively. However, given the current institutional structures and processes through which economic sanctions are imposed, these coercive actions are neither the most effective nor a just means of pursuing either of the two goals that are meant to animate them.

\section{UN SANCTIONS ON AfGHanistan: A FemInIST PERSPEctive}

\section{by Barbara Stark}

There are obviously many feminist methods that can be used to analyze the effects of UN sanctions against Afghanistan. I draw on the four methods identified in Katharine Bartlett's article, "Feminist Legal Methods," to analyze those sanctions from a feminist perspective.

\section{Asking the Women Question}

Have women been left out of consideration? If so, how can the omission be corrected? First, the sanctions model assumes political accountability, which is conspicuously lacking in this case. In fact, women have no civil or political rights. They are subject to arbitrary corporal punishment and excluded from political life. Second, as the SecretaryGeneral and others have noted, the most economically vulnerable are the hardest hit by sanctions. Afghan women are among the most economically vulnerable in the world because they are routinely denied education, health care, and employment as a matter of state policy.

\section{Feminist Practical Reasoning}

This method combines Aristotelian practical deliberation with a "feminist focus on identifying and taking into account the perspectives of the excluded. ... Not only the resolution of the problem, but even what counts as a problem, emerges from the specifics of the situation itself." Thus, the problem here is not a dichotomized conflict (surrender Osama bin Laden or suffer the wrath of the West) but a complex dilemma in which violations of women's human rights, at every conceivable level, demand sustained but flexible strategies. UNICEF, for example, has refused to support Afghan schools as long as girls are excluded.

\section{Consciousness Raising}

Consciousness raising operates on a public institutional level by bearing witness to and challenging patriarchy through lobbying, politics, media, and other avenues of norm building, including Security Council resolutions. For Afghan women, feminist metaphors are a grim reality. Women's "silences" and "invisibility" are enforced by religious police. Although the gross violations of women's human rights are well-documented, they are not a priority of the international community.

\section{Positionality}

Positionality recognizes feminist commitments but views them as provisional, subject to ongoing evaluation. It encourages a series of strategic moves aimed at assuring Afghan women the freedom to set their own commitments. As Christine Chinkin and Hillary

\footnotetext{
- Professor of Law, University of Tennessee College of Law.
} 
Charlesworth affirm, international law is "capable of transforming justice and order and of distributing power and resources to the greater benefit of women." Nowhere is this a more urgent priority than in Afghanistan.

\section{AN INTERNATIONAL RELATIONS THEORY APPROACH}

\section{by Anne-Marie Slaughter}

International relations (IR) theory does not provide determinate legal answers; it is not a jurisprudential tool but rather a tool to situate doctrines in the context of international politics and sort out the underlying policy arguments. That process can, in turn, yield doctrinal orientations.

In particular, IR theory may be used as a diagnostic tool to figure out what is wrong with the current sanctions policy. From a realist perspective, sanctions are a tool of power politics. If they are not working, they must be tightened or strengthened. From an institutionalist perspective, sanctions can only work if there is a genuine convergence of interest among nations, in which case an institution such as the United Nations or a regional institution can help solve the collective action problems. If sanctions are not working, it is likely due to problems with institutional design, such that individual states still have an incentive to defect from the sanctions regime in their own interest, or because the necessary convergence of interests does not exist in the first place.

From a liberal perspective, sanctions will only work if they are supported by powerful interest groups in the sanctioning nation and if they have an impact on powerful groups in the sanctioned nation. From this perspective, a failure of effectiveness is either due to weakness of will on the part of the nations doing the sanctioning (in this case, lack of support from business interests and transnational humanitarian interest groups) or because the sanctions have no actual impact on those domestic groups that have the ability to change policy in the sanctioned nation. Again, there is considerable support for this view as well, given the agitation of the U.S. business community, the increased awareness of the humanitarian impact of the disaster through transnational NGO networks, and the resulting ebb in support for the sanctions both on moral grounds and because they are seen as being ineffective.

Since the real world is multicausal, all these different strands are probably operating. Nevertheless, it is helpful to be able to identify and to distinguish them. But having diagnosed the problem from these different perspectives, what can we do about it?

Each paradigm offers a different prescription. (1) Realists would argue for strengthening the sanctions. (2) Institutionalists would argue either for dropping the sanctions for lack of convergent interests or for getting the powers most interested in imposing the sanctions to offer side payments to nations most likely to defect, enhancing monitoring ability and disciplinary measures for noncompliance with the sanctions regime. (3) Liberals would work to build a domestic constituency for the sanctions but would also seek to target the sanctions more directly to affect leaders and top policy makers.

To affect the behavior of Taliban leaders, it may well be necessary not only to freeze their assets but to threaten them with expulsion from certain Islamic fora, to deny them the opportunity to travel to Mecca or other Islamic holy places, to deny medical treatment outside Afghanistan for family members of Taliban members, and so forth. To

- J.Sinclair Armstrong Professor of International, Foreign and Comparative Law and Director of Graduate and International Studies at Harvard Law School. 